\title{
Structure-activity relationship study of glaziovianin A against cell cycle progression and spindle formation of HeLa $S_{3}$ cells
}

\author{
Akiyuki Ikedo ${ }^{\text {a }}$, Ichiro Hayakawa ${ }^{\text {a }}$, Takeo Usui ${ }^{b}$, Sayaka Kazami ${ }^{\text {c,d }}$, Hiroyuki Osada ${ }^{\mathrm{d}}$, \\ Hideo Kigoshi ${ }^{\text {a,* }}$ \\ ${ }^{a}$ Department of Chemistry, Graduate School of Pure and Applied Sciences, University of Tsukuba, Tennodai, Tsukuba, 305- \\ 8571, Japan \\ ${ }^{\mathrm{b}}$ Graduate School of Life and Environmental Sciences, University of Tsukuba, Tennodai, Tsukuba, 305-8572, Japan \\ ${ }^{\mathrm{c}}$ Graduate School of Science and Engineering, Saitama University, 255, Shimo-okubo, Sakura-ku, Saitama 338-0825, \\ Japan \\ ${ }^{\mathrm{d}}$ Chemical Biology Department, RIKEN Advanced Science Institute, Wako, Saitama 351-0198, Japan
}

Received Month XX, 2000; Accepted Month XX, 2000

\begin{abstract}
Various derivatives of glaziovianin A, an antitumor isoflavone, were synthesized, and the cytotoxicity of each against HeLa $\mathrm{S}_{3}$ cells was investigated. Compared to glaziovianin $\mathrm{A}$, the $O^{7}$-allyl derivative was found to be more cytotoxic against $\mathrm{HeLa} \mathrm{S}_{3}$ cells and a more potent M-phase inhibitor. (C2000 Elsevier Science Ltd. All rights reserved.
\end{abstract}

In 2007, glaziovianin A (1) was isolated from the leaves of the Brazilian tree Astelia glazioviana by Yokosuka et al. (Fig. 1). ${ }^{1}$ Glaziovianin A (1) exhibited cytotoxicity against $\mathrm{HL}-60$ cells with an $\mathrm{IC}_{50}$ value of $0.29 \mu \mathrm{M}$. Also, glaziovianin A (1) was evaluated against a panel of 39 human cancer cell lines (termed JFCR39) at the Japanese Foundation for Cancer Research. The pattern of the differential cytotoxicities of glaziovianin A (1) has suggested that the activity of glaziovianin A (1) involves the inhibition of tubulin polymerization as a mechanism of action. ${ }^{2}$ Inhibitors of tubulin polymerization have become clinically important drugs against breast cancer. Because glaziovianin A showed antitumor activities in a mouse xenograft model (unpublished data), we think that modification of glaziovianin A (1) can lead to the discovery of novel compounds that possess antitumor activity and that inhibit tubulin polymerization. In this paper, we report the structure-activity relationship study of glaziovianin A (1).

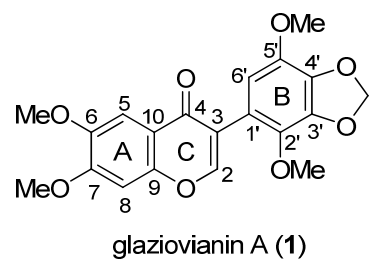

Figure 1. Structure of glaziovianin A (1).

We previously reported the synthesis of glaziovianin A (1) by using Suzuki-Miyaura coupling as a key step (Scheme 1). ${ }^{3}$ The method of synthesizing glaziovianin A analogues was based on our previous strategy. To develop analogues of glaziovianin A (1), its structure can be divided into two structural moieties: an A-ring and a B-ring (Fig. 2). Therefore, we synthesized 3iodochromone derivatives as an A-ring and borone compounds as a B-ring. 
<smiles>COc1cc(O)c(C(C)=O)cc1OC</smiles><smiles>COc1ccc(OC)c2c1OCO2</smiles><smiles>COc1cc2occ(I)c(=O)c2cc1OCC(C)(C)OC(C)(C)C</smiles><smiles>COc1cc2occ(-c3cc(OC)c4c(c3OC)OCO4)c(=O)c2cc1OC</smiles>

Scheme 1. Total synthesis of glaziovianin A (1) by our group.
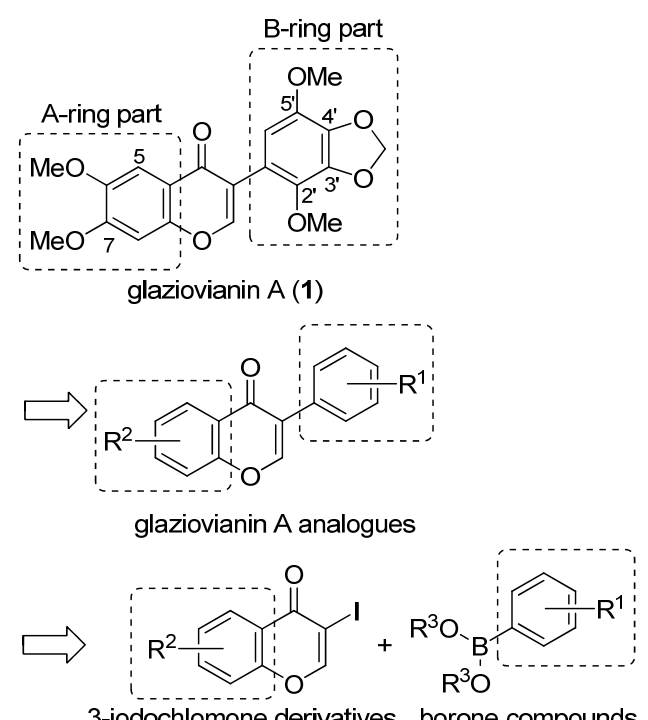

Figure 2. Key structural moieties of glaziovianin A.

First, we tried to modify a methylene acetal part at the B-ring of glaziovianin A (Scheme 2). The diol group in 3,6-dimethoxybenzene-1,2-diol (6) was converted to compound 7. The bromination of compound 7 gave a monobromo compound, which was converted into arylboronate 8. $^{4} \quad 2,3,4,5$-Tetramethoxyphenylboronic acid (10) was prepared by the lithiation of 1,2,3,4tetramethoxybenzene (9) followed by treatment with trimethyl borate. ${ }^{5}$ The Suzuki-Miyaura coupling ${ }^{6}$ of 3iodo-6,7-dimethoxy-4H-chromen-4-one $(3)^{3}$ with boron compounds, such as arylboronate 8, 2,3,4,5tetramethoxyphenylboronic acid (10), or commercially available 3,4-(methylenedioxy)phenylboronic acid (11), afforded glaziovianin A analogues 12-14, respectively.

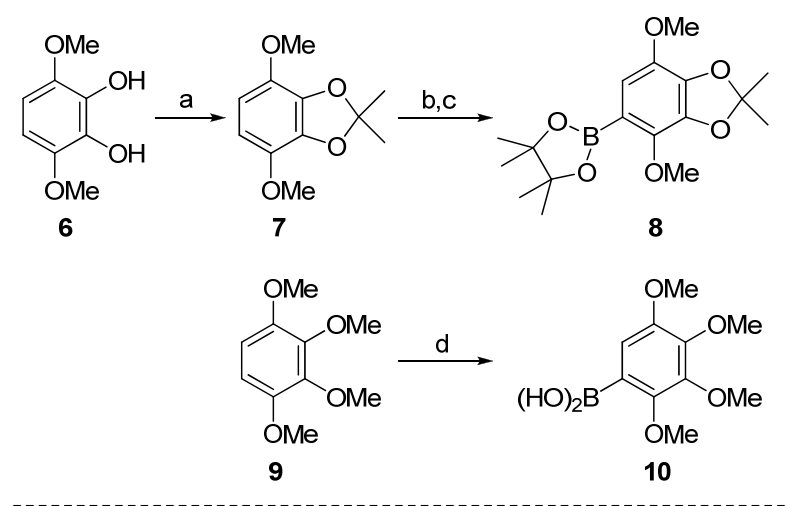

$$
\begin{aligned}
& \text { (l) } \\
& 8 R^{1}, R^{1}=\xi_{-0}^{\xi-O} X \\
& \mathrm{R}^{2}=\mathrm{OMe}, \mathrm{R}^{3}=\text { Bpin } \\
& 10 \mathrm{R}^{1}=\mathrm{R}^{2}=\mathrm{OMe} \\
& \mathrm{R}^{3}=\mathrm{B}(\mathrm{OH})_{2} \\
& \left.11 R^{1}, R^{1}=\begin{array}{l}
\xi-O \\
\xi-O
\end{array}\right\rangle \\
& 12 R^{1}, R^{1}=\xi_{-O} X, R^{2}=O M e \\
& 13 \mathrm{R}^{1}=\mathrm{R}^{2}=\mathrm{OMe} \\
& \left.14 R^{1}, R^{1}=\underset{\xi-O}{\xi-O}\right\rangle, R^{2}=H \\
& \mathrm{R}^{2}=\mathrm{H}, \mathrm{R}^{3}=\mathrm{B}(\mathrm{OH})_{2}
\end{aligned}
$$

Scheme 2. Synthesis of B-ring analogues of glaziovianin A. Reagents and conditions: (a) 2-methoxypropene, PPTS, benzene, rt, 72\%; (b) NBS, DMF, rt, 69\%; (c) bis(pinacolato)diboron, $\mathrm{PdCl}_{2}$ (dppf), KOAc, DMF, $150{ }^{\circ} \mathrm{C}, 28 \%$; (d) $n$-BuLi, B(OMe) $)_{3}$, THF, rt; (e) $3, \mathrm{PdCl}_{2}$ (dppf), $1 \mathrm{M}$ $\mathrm{Na}_{2} \mathrm{CO}_{3}$ aq., 1,4 -dioxane, rt $\{64 \%$ for $12,11 \%$ for 13 (from 9 ), $41 \%$ for $14\}$.

Next, we prepared A-ring analogues. Selective protection of the hydroxy group at the $\mathrm{C} 7$ position of $15^{7}$ afforded compound 16 (Scheme 3). Condensation of 16 with $N, N$-dimethylformamide dimethyl acetal gave an enamine, which was converted to iodochromone 17.8 We tried a cross coupling reaction with arylboronate $5^{3}$ and iodochromone compounds, such as $\mathbf{1 7}$ or $18^{9}$, to provide compounds 19 and 20, respectively. The THP group in 19 was removed by using $p-\mathrm{TsOH} \cdot \mathrm{H}_{2} \mathrm{O}$ to give a 7-hydroxy derivative (21), which is a suitable precursor for the synthesis of glaziovianin derivatives. Conversion of the hydroxy group at C7 in 21 into various ethers afforded benzyl ether 22, propargyl ether 23, and allyl ether 24. 


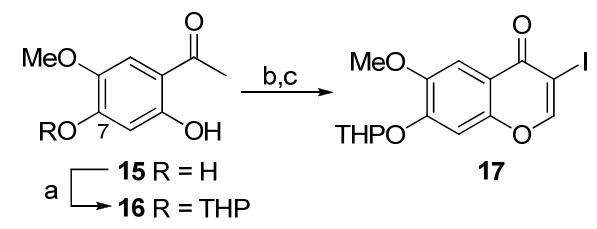<smiles>[R6]Oc1cc2occ(I)c(=O)c2c([R4])c1OC</smiles>
$\begin{array}{ll}17 R^{4}=H, R^{5}=\text { THP } & 19 R^{4}=H, R^{5}=\text { THP } \\ 18 R^{4}=O M e, R^{5}=M e & 20 R^{4}=O M e, R^{5}=M e\end{array}$<smiles>C#CCOc1cc2occ(-c3cc(OC)c4c(c3OC)OCO4)c(=O)c2cc1OC</smiles>

Scheme 3. Synthesis of A-ring analogues of glaziovianin A. Reagents and conditions: (a) DHP, PPTS, $\mathrm{CH}_{2} \mathrm{Cl}_{2}, \mathrm{rt}, 80 \%$; (b) $\mathrm{Me}_{2} \mathrm{NCH}(\mathrm{OMe})_{2}, 90{ }^{\circ} \mathrm{C}$, quant; (c) $\mathrm{I}_{2}$, pyr, $\mathrm{CHCl}_{3}$, rt, $70 \%$; (d) 5, $\mathrm{PdCl}_{2}$ (dppf), $1 \mathrm{M} \mathrm{Na}_{2} \mathrm{CO}_{3}$ aq., 1,4-dioxane, rt $\left(66 \%\right.$ for $19,16 \%$ for 20); (e) $p-\mathrm{TsOH} \cdot \mathrm{H}_{2} \mathrm{O}, \mathrm{MeOH}$, $\mathrm{CHCl}_{3}$, rt, $85 \%$; (f) benzyl bromide, $\mathrm{K}_{2} \mathrm{CO}_{3}, \mathrm{MeCN}$, rt, $80 \%$; (g) allyl bromide, $\mathrm{K}_{2} \mathrm{CO}_{3}, \mathrm{MeCN}$, rt, $78 \%$; (h) propargyl bromide, $\mathrm{K}_{2} \mathrm{CO}_{3}, \mathrm{MeCN}$, rt, $70 \%$.

Table 1 summarizes the cytotoxicity of glaziovianin A (1) and its analogues against $\mathrm{HeLa} \mathrm{S}_{3}$ cells. $^{10}$ Compound 12, which has an acetonide group instead of the methylene acetal group, showed no cytotoxicity even at $100 \mu \mathrm{M}$. Also, compound 13, which has four methoxy groups at the B-ring, was about 40-fold less cytotoxic than glaziovianin A (1). These results indicated that steric hindrance of C3' and C4' at the Bring part was shown to reduce cytotoxicity to a large extent. Compound 14, which lacks methoxy groups at C2' and C5', was less cytotoxic than glaziovianin A (1), which indicated that the electron density of the B-ring might be essential for cytotoxicity. On the other hand, compound 20, which has an extra methoxy group at $\mathrm{C} 5$ of the A-ring, showed no cytotoxicity at $100 \mu \mathrm{M}$. This result showed that the steric hindrance and electron density of the A-ring reduced cytotoxicity to a large extent. While the 7-demethyl derivative $\mathbf{2 1}$ exhibited no cytotoxicity, compounds 22-24, which each have an alkyl group at $\mathrm{O}^{7}$ instead of the methyl group, showed cytotoxicity with $\mathrm{IC}_{50}$ values of $0.75,0.74$, and $0.19 \mu \mathrm{M}$, respectively. Furthermore, compound 19, which has a
THP group at $\mathrm{O}^{7}$, showed no cytotoxicity even at $100 \mu \mathrm{M}$. These results indicated that the hydrophobicity of the $O^{7}$-alkyl group in glaziovianin derivatives is important for cytotoxicity. However, the THP group seems to be too large. It is worth noting that allyl ether $\mathbf{2 4}^{11}$ is more active than glaziovianin A (1) itself.

Table 1. Cytotoxicity of glaziovianin A (1) and its analogues against $\mathrm{HeLa} \mathrm{S}_{3}$ cells.

\begin{tabular}{ccc}
\hline & \multicolumn{2}{c}{ cytotoxicity } \\
compound & $\mathrm{IC}_{50}(\mu \mathrm{M})$ & relative value \\
\hline glaziovianin A (1) & 0.59 & 1 \\
$\mathbf{1 2}$ & $>100$ & - \\
$\mathbf{1 3}$ & 22.0 & 0.027 \\
$\mathbf{1 4}$ & 56.2 & 0.010 \\
$\mathbf{1 9}$ & $>100$ & - \\
$\mathbf{2 0}$ & $>100$ & - \\
$\mathbf{2 1}$ & $>100$ & - \\
$\mathbf{2 2}$ & 0.75 & 0.79 \\
$\mathbf{2 3}$ & 0.74 & 0.80 \\
$\mathbf{2 4}$ & 0.19 & 3.1 \\
\hline
\end{tabular}

We previously reported that glaziovianin A (1) inhibited the cell cycle progression in the M-phase with abnormal spindle structures. Therefore, we next investigated the effects of the most cytotoxic compound, 24, on both cell cycle progression $^{12}$ and spindle structures ${ }^{13}$ (Figure 3 ). As with glaziovianin A (1), compound 24 inhibited cell cycle progression in $\mathrm{M}$-phase, and 24-treated cells showed abnormal spindle structures with unaligned chromosomes at the concentration of $1 \mu \mathrm{M}$ after $18 \mathrm{~h}$ treatment: these phenotypes were stronger than those of $1 \mu \mathrm{M}$ glaziovianin A (1) treatment, suggesting that compound $\mathbf{2 4}$ is a more potent M-phase inhibitor than the original compound glaziovianin A (1).
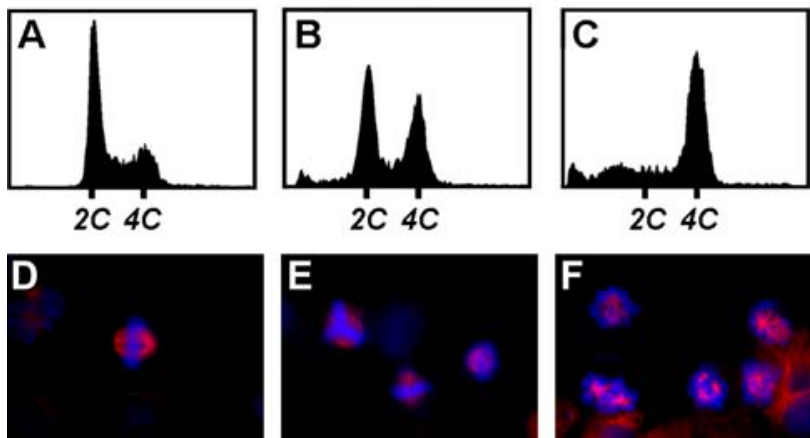

Figure 3. Effects of glaziovianin A (1) and compound 24 on cell cycle progression and spindle structures in HeLa $\mathrm{S}_{3}$ cells. Effects of $\mathbf{1}$ and $\mathbf{2 4}$ on cell cycle progression $(\mathrm{A}-\mathrm{C})$ and spindle structures (D-F) in HeLa $\mathrm{S}_{3}$ cells. HeLa $\mathrm{S}_{3}$ cells were treated with DMSO (A and D), $1 \mu \mathrm{M}$ of glaziovianin $\mathrm{A}$ (1) (B and E), or compound $24(\mathrm{C}$ and $\mathrm{F})$ for $18 \mathrm{~h}$. Microtubules (red) and chromosomes (blue) are shown in D-F. Microtubules and chromosomes were stained with anti- $\alpha$-tubulin antibody (DM1A, Sigma) and Hoechst 33258, respectively.

In conclusion, we have investigated the structurecytotoxicity relationships of glaziovianin A (1). From this work, we developed the $O^{7}$-allyl compound 24 as much more cytotoxic than glaziovianin A (1) against $\mathrm{HeLa} \mathrm{S}_{3}$ cells. Further studies on the synthesis of $\mathrm{O}^{7}$ - 
modified probe molecules of glaziovianin A (1) for searching target biomolecules are currently in progress.

\section{Acknowledgments}

This work was supported in part by Grants-in-Aid for Scientific Research (B), and Scientific Research on Priority Area "Creation of Biologically Functional Molecules" from the Ministry of Education, Culture, Sports, Science and Technology (MEXT), Japan.

\section{References and Notes}

1. Yokosuka, A.; Haraguchi, M.; Usui, T.; Kazami, S.; Osada, H.; Yamori, T.; Mimaki, Y. Bioorg. Med. Chem. Lett. 2007, 17, 3091.

2. Yamori, T.; Matsunaga, A.; Saito, S.; Yamazaki, K.; Komi, A.; Ishizu, K.; Mita, I.; Edatsugi, H.; Matsuda, Y.; Takezawa, K.; Nakanishi, O.; Kohno, H.; Nakajima, Y.; Komatsu, H.; Andoh, T.; Tsuruo, T. Cancer Res. 1999, 59, 4042.

3. Hayakawa, I.; Ikedo, A.; Kigoshi, H. Chem. Lett. 2007, 36, 1382.

4. Ishiyama, T.; Murata, M.; Miyaura, N. J. Org. Chem. 1995, 60, 7508.

5. Tremblay, S. M.; Sames, D. Org. Lett. 2005, 7, 2417.

6. Hoshino, Y.; Miyaura, N.; Suzuki, A. Bull. Chem. Soc. Jpn. 1988, 61, 3008.

7. Adityachaudhury, N.; Kirtaniya, C. L.; Mukherjee, B. Tetrahedron 1971, 27, 2111.

8. Gammill, R. B. Synthesis 1979, 901.

9. Igarashi, Y.; Kumazawa, H.; Ohshima, T.; Satomi, H.; Terabayashi, S.; Takeda, S.; Aburada, M.; Miyamoto, K. Chem. Pharm. Bull. 2005, 53, 1088.

10. Cell survival was determined by a WST-8 assay kit (Dojindo Laboratories, Kumamoto, Japan). HeLa $\mathrm{S}_{3}$ cells $\left(3 \times 10^{3}\right.$ cells/well $)$ in 96 well plates were incubated overnight. Then, cells were treated with various concentrations of each compounds. After $48 \mathrm{~h}$ incubation, $10 \mu \mathrm{l}$ of WST- 8 reagents were added to the culture. After $2 \mathrm{~h}$ incubation, the absorbance at $450 \mathrm{~nm}$ was measured with iMark microplate reader (BioRad Laboratories, Inc). Absorbance correlates with the number of living cells. The number of living cells (\% control) was calculated with the following formula: (each absorbance - absorbance of blank well)/absorbance of $0 \mu \mathrm{M}$ well $\times 100$.

11. Chemical data for compound $24:{ }^{1} \mathrm{H}$ NMR (400 MHz, $\left.\mathrm{CDCl}_{3}\right) \delta 7.89(\mathrm{~s}, 1 \mathrm{H}), 7.62(\mathrm{~s}, 1 \mathrm{H}), 6.89(\mathrm{~s}, 1 \mathrm{H}), 6.52$ $(\mathrm{s}, 1 \mathrm{H}), 6.11$ (ddt, $J=17.6,10.5,5.4 \mathrm{~Hz}, 1 \mathrm{H}), 6.02$ (s, 2H), 5.48 (ddt, $J=17.6,1.4,1.4 \mathrm{~Hz}, 1 \mathrm{H}), 5.38$ (ddt, $J$ $=10.5,1.4,1.4 \mathrm{~Hz}, 1 \mathrm{H}), 4.72(\mathrm{dt}, J=5.4,1.4 \mathrm{~Hz}, 2 \mathrm{H})$, $3.98(\mathrm{~s}, 3 \mathrm{H}), 3.87(\mathrm{~s}, 3 \mathrm{H}), 3.85(\mathrm{~s}, 3 \mathrm{H}) ;{ }^{13} \mathrm{C} \mathrm{NMR}$ $\left(67.8 \mathrm{MHz}, \mathrm{CDCl}_{3}\right) \delta 175.2,154.4,153.4,152.0$, $147.8,139.0,138.9,137.0,136.6,135.8,121.5,118.0$, $117.7,116.5,110.0,105.2,101.8,100.9,73.3,62.1$, 57.0, 56.4; IR $\left(\mathrm{CHCl}_{3}\right) 3008,2938,1639,1607,1503$, $1469,1430,1399,1349,1298,1267,1231,1195$, 1153, 1099, 1063, 1035, 995, 833, $697 \mathrm{~cm}^{-1}$; ESIMS $\mathrm{m} / \mathrm{z}$ 435.1057, calcd for $\mathrm{C}_{22} \mathrm{H}_{20} \mathrm{NaO}_{8} \quad[\mathrm{M}+\mathrm{Na}]^{+}$ 435.1056 .

12. Flow cytometry was used to analyses the distribution of DNA content in the cell populations. The cells were fixed with cold $\left(-20{ }^{\circ} \mathrm{C}\right) 70 \% \mathrm{EtOH}(\mathrm{v} / \mathrm{v})$ and stained with propidium iodide (Sigma). Total fluorescence intensities were determined by quantitative flow cytometry with CyFlow PA (Partec $\mathrm{GmbH}$, Munster, Germany).

13. Immunofluorescence observation of tubulin was performed as described in previous paper. ${ }^{14}$ The DNA and microtubules were photographed with Leica AF6000 (Leica Microsystems GmbH, Wetzlar, Germany).

14. Kondoh, M.; Usui, T.; Nishikiori, T.; Mayumi, T.; Osada, H. Biochem. J. 1999, 340, 411. 